\title{
Identification of various Biomphalaria alexandrina strains collected from five Egyptian governorates using RAPD and species-specific PCR techniques
}

\author{
A. M. Mohamed ${ }^{1}$, A. T. Sharaf El-Din ${ }^{2}$, A. H. Mohamed ${ }^{1}$, M. R. Habib ${ }^{2}$
}

${ }^{1}$ Zoology Department, Faculty of Science, Menoufiya University, Shibin EL Kom, Egypt;

${ }^{2}$ Medical Malacology Department, Theodor Bilharz Research Institute, Giza, Egypt.

Email: techniquesahmadsharafeldin@yahoo.com

Received 11 January 2011; revised 1 March 2011; accepted 8 March 2011.

\begin{abstract}
The first generation of Biomphalaria snails collected from five Egyptian governorates (Giza, Fayoum, Kafr El-Sheikh, Ismailia and Damietta) were subjected to species-specific PCR assays and the results showed that snails collected from the field were $B$. alexandrina, and there was no evidence for the presence of $B$. glabrata. The snails were subjected also to RAPD-PCR technique. The results showed that different fingerprints with each $B$. alexandrina strain were produced with varying numbers of bands ranging in size from 123.6 to 796.6 bp depending on the snail strain and the primer used. Many specific bands were obtained with the four primers in each strain. Primer OPA-1 amplified the highest number of specific bands (26 bands) and gave the highest polymorphism among the primers used $(100 \%$ polymorphism). The estimated similarity coefficients among $B$. alexandrina strains based on the RAPD-PCR profiles ranged from 0.56 to 0.72 . The highest similarity coefficient ( 0.72$)$ was recorded between the strains of Ismailia and Kafr El-Sheikh, while the lowest coefficient (0.56) was reported between the strains of SPSC and Ismailia.
\end{abstract}

Keywords: Biomphalaria Alexandrina; Egypt; Rapd; Species-Specific; Pcr

\section{INTRODUCTION}

Morphological studies of Biomphalaria species identification have been widely carried out and differentiation between some species may be difficult mainly due to phenotypic similarities, size of collected specimens and inadequate fixation procedures [1]. Identification of Biomphalaria species is important to further understand the schistosomiasis epidemiology. Considering the fact that morphological identification may become difficult or even impossible under particular circumstances, the use of molecular-based methods have permitted the generation of more consistent information concerning the population structure of Biomphalaria furthering knowledge on taxonomy and diagnosis of infection. In addition to variation in snail susceptibility and parasite infectivity, the host species identification constitutes an important issue due to morphological similarities, host snail populations have been sometimes misidentified as refractory, which, actually, do not constitute a host species [2]. DNA markers provide opportunity for genetic characterization and allow direct comparison of different genetic material independent of environmental influences [3].

Kristensen et al. [4] utilized RAPD-PCR to differentiate species and populations of Biomphalaria from Egypt and other countries. They confirmed that in Nile Delta $B$. glabrata as well as $B$. alexandrina is living in the field and it appeared that the hybridization may be occurring between the two. However, Lofty et al. [5] reported that Biomphalaria snails were widely distributed in the Nile Delta and along the Nile as far south as Aswan. According to the results of species-specific polymerase chain reaction assays that sampled both nuclear and mitochondrial genomes, and according to DNA sequence data, they found that all Biomphalaria collected during this survey were $B$. alexandrina and there was no evidence of the presence of B. glabrata or of hybridization of $B$. alexandrina with $B$. glabrata in the examined sites.

The present study was initiated to identify Biomphalaria snails collected from certain water courses in 5 Egyptian governorates during 2009 using species specific PCR assay and calculating the similarity coefficients among different snail strains collected from these governorates using RAPD-PCR of their DNA. 


\section{MATERIALS AND METHODS}

\subsection{Collection of Biomphalaria Snails:}

In this study, populations of Biomphalaria snails from some water courses in 5 Egyptian (Giza, Fayoum, Kafr El-Sheikh, Ismailia and Damietta) were collected and reared in the laboratory and their offspring $\left(F_{1}\right)$ were used throughout this study. Another snail population was obtained from Schistosome Biological Supply Center-Theodor Bilharz Research Institute (SBSC-TBRI) which served as a B. alexandrina reference control. Also, B. glabrata snails were obtained from Medical Malacology Department (TBRI).

\subsection{DNA Extraction:-}

Three lab-bred snails from each governorate were dissected for DNA extraction [6,7]. Briefly, snails head-foot regions were dissected then powdered in liquid nitrogen using a mortar and pestle and transferred to a centrifuge tube containing $15 \mathrm{ml}$ of pre heated $\left(60^{\circ} \mathrm{C}\right)$ CTAB buffer (2\%w/v CTAB, $1.4 \mathrm{M} \mathrm{NaCl}, 0.2 \% \mathrm{v} / \mathrm{v} \beta$-mercaptoethanol, $20 \mathrm{mM}$ EDTA, $100 \mathrm{mM}$ Tris $\mathrm{HCl} \mathrm{pH} 8,0.1 \mathrm{mg} / \mathrm{ml}$ proteinase $\mathrm{K}$ ). After incubation at $60^{\circ} \mathrm{C}$ for 30 minutes, the suspension was extracted with an equal volume of phenol: chloroform: isoamylalcohol (25: $24: 1)$. After centrifugation (8000 r.p.m., $10 \mathrm{~min}$ ), the aqueous phase was incubated with $5 \mathrm{ml}$ RNase for 1 hour at $37^{\circ} \mathrm{C}$. DNA was extracted with an equal volume of chloroform: isoamylalcohol (24 : 1). After centrifugation (8000 r.p.m., 10 $\mathrm{min}$ ), the aqueous phase was transferred to a centrifuge tube. DNA was precipitated by adding $\sim 2 / 3$ volume isopropanol and gently inverting the tube and leaving overnight at room temperature DNA was then collected by centrifugation at 8000 r.p.m. for 10 minutes. DNA was washed in $76 \%$ ethanol, $10 \mathrm{mM}$ ammonium acetate for 30 minutes and recovered by centrifugation (8000 r.p.m., $10 \mathrm{~min}$ ). After air drying the DNA was dissolved in 20 $\mu \mathrm{l}$ deionized water, and the DNA concentration was estimated using $2 \%$ agarose gel electrophoresis.

\subsection{DNA Amplification: -a-Species-Specific PCR}

Two pairs of species-specific primers (Genetech-Egypt) were used [5] (Table 1). One primer pair (GITS2F1 and GITS2R1) was used to amplify an approximately 361bp fragment of B. glabrata ITS2. While a second primer pair (AITS1F1 and AITS1R1) was used to amplify a 316 bp fragment of $B$. alexandrina ITS1. The volume of each amplification reaction was $20 \mu \mathrm{l}$ with: $4 \mu \mathrm{l}$ (approximately $200 \mathrm{ng}$ ) of DNA, $0.8 \mathrm{mM}$ dNTPs, $2 \mathrm{mM} \mathrm{MgCl}_{2}$, $0.5 \mu \mathrm{M}$ of each primer, 0.5 unit Taq DNA Polymerase (Promega), and buffer. For B. alexandrina ITS1 and $B$. glabrata ITS2 (AITS1F1, AITS1R1, GITS2F1 and GITS2R1) primers the thermocycler (Whatman Biometra T Gradient) was programmed as follows, with a $1^{\circ} \mathrm{C}$ per second rate of change: 1 cycle of $95^{\circ} \mathrm{C}$ for $1 \mathrm{~min}$, $62^{\circ} \mathrm{C}$ for $2 \mathrm{~min}$, and $74^{\circ} \mathrm{C}$ for $1 \mathrm{~min} 30 \mathrm{~s}$, followed by 30 cycles of $95^{\circ} \mathrm{C}$ for $30 \mathrm{~s}, 62^{\circ} \mathrm{C}$ for $30 \mathrm{~s}, 74^{\circ} \mathrm{C}$ for 1 min 30 $\mathrm{s}$, plus a final extension step for $7 \mathrm{~min}$.

RAPD-PCR reactions were conducted using four random primers (Matrix-Egypt) with the sequences shown in Table 2.

The reaction conditions were optimized and the mixtures ( $25 \mu \mathrm{l}$ total volume) consisted of the following: 3.0 $\mu \mathrm{l}$ dNTPs (2.5 mM), $2.5 \mu \mathrm{lgCl}_{2}(25 \mathrm{mM}), 2.5 \mu \mathrm{l} 10 \mathrm{x}$ buffer, $5.0 \mu$ primer $(10 \mathrm{mM}), 1.0 \mu$ lemplate DNA (50 $\mathrm{ng} / \mu \mathrm{l}), 0.2 \mu \mathrm{l}$ Taq polymerase ( 5 units/ $\mu \mathrm{l}$ ) and up to 25 $\mu \mathrm{l}$ sterile and distilled $\mathrm{H}_{2} \mathrm{O}$.

Amplification was carried out in a thermal cycler (Eppendorf, Germany) programmed for initial denaturation step at $95^{\circ} \mathrm{C}$ for 5 minutes followed by 40 cycle each at $95^{\circ} \mathrm{C}$ for $1 \mathrm{~min}$, annealing temperature at $30^{\circ} \mathrm{C}$ for $1 \mathrm{~min}$, polymerization temperature at $72^{\circ} \mathrm{C}$ for $1 \mathrm{~min}$ and a final extension step at $72^{\circ} \mathrm{C}$ for $10 \mathrm{~min}$.

Table 1. Species-specific primers used in the present study.

\begin{tabular}{|c|c|c|}
\hline Amplified region & $\begin{array}{c}\text { Forward primer (species-specific difference } \\
\text { sites) }\end{array}$ & $\begin{array}{l}\text { Reverse primer (species-specific differ- } \\
\text { ence sites) }\end{array}$ \\
\hline $\begin{array}{l}\text { B. alexandrina ITS1 spe- } \\
\text { cies-specific primers }\end{array}$ & $\begin{array}{c}\text { AITS1F1 (4 sites) } \\
\text { 5`-TTG CTA TCG ACG ATA ACA GCA C-3` }\end{array}$ & $\begin{array}{c}\text { AITS1R1 (2 sites) } \\
\text { 5`-AGG GGC ATA GGT ACC CTG GAA } \\
\text { C-3` }\end{array}$ \\
\hline $\begin{array}{l}\text { B. glabrata ITS2 spe- } \\
\text { cies-specific primers }\end{array}$ & $\begin{array}{c}\text { GITS2F1 (7 sites) } \\
\text { 5`CTG CTG GTG TTA TGG GTT TCC C-3` }\end{array}$ & $\begin{array}{c}\text { GITS2R1 (12 sites) } \\
\text { 5`-CCG ATC TGA GGT CGG AGA TTA } \\
\text { A-3` }\end{array}$ \\
\hline
\end{tabular}

b- RAPD- PCR

Table 2. List of the random primers used in RAPD-PCR analysis and their nucleotide sequences.

\begin{tabular}{|c|c|c|}
\hline Number & Name & 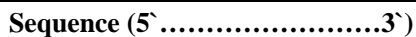 \\
\hline $1-$ & OPA-18 & AGG TGA CCG T \\
\hline $2-$ & OPA-9 & GGG TAA CGC C \\
\hline $3-$ & LROR & ACC CGC TGA ACT TAA GC \\
\hline $4-$ & OPA-1 & CAG GCC CTT C \\
\hline
\end{tabular}




\subsection{Detection of the Amplified Products}

Electrophoresis through agarose gel is the standard method used to separate, identify and purify DNA fragments [8]. The technique is simple, rapid to perform and capable of resolving fragments of DNA that can not be separated adequately by other procedures, such as density gradient centrifugation. Furthermore, the location of DNA within the gel is determined directly by staining with low concentration of the fluorescent intercalating dye ethidium bromide, bands containing as little as $10 \mathrm{ng}$ of DNA can be detected by direct examination of the gel in UV light.

\subsection{Gel Analysis}

Gels were scanned visually to detect the generated bands. The size of the detected bands were determined using DNA ladder (Promega, USA) with molecular weights 3000, 1500, 1000, 900, 800, 700, 600, 500, 400, 300, 200, 100 bp.

\subsection{Scoring and Data Analysis for RAPDs}

The DNA bands were scored for their presence (1) or absence (0) in the RAPD profile of various snail strains. Only sharp bands were scored (not "ghost”) using GelAnalyzer3 (Egygene) software. Unequivocally reproducible bands were scored and entered in a binary character matrix ( 1 for present and 0 for absence). The genetic similarity among isolates was determined by Nie's genetic distance [9]. A dendrogram was constructed based on the matrix of genetic similarity using Unweighted Pair Group Method with Arithmetic Average (UPGMA). All calculations were performed by using the NTSYS-pc 2.02 software package (Numerical Taxonomy System, Exeter Sostware) [10].

\section{RESULTS}

\subsection{Identification of Biomphalaria Species Using PCR:-}

Species-specific PCR assay using B. glabrata ITS2 primers yielded the expected 361 bp product only with the control laboratory B. glabrata strain (SBSC-TBRI). While no products were obtained with any of the Biomphalaria strains collected from the field (Figure 1(a)). $B$. alexandrina ITS1 primers yielded the expected 316 bp product only when $B$. alexandrina DNA was present (Figure 1(b)). The collected Biomphalaria snails from Giza, Fayoum and Kafr El-Sheikh gave positive results indicating that these snails are B. alexandrina.

According to the results of these assays, Biomphalaria snails collected from the field were $B$. alexandrina in collected samples, and there was no evidence of the presence of B. glabrata. Positive and negative controls

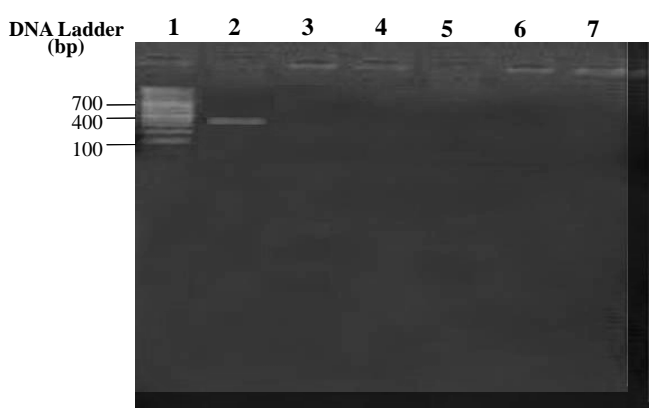

(a)

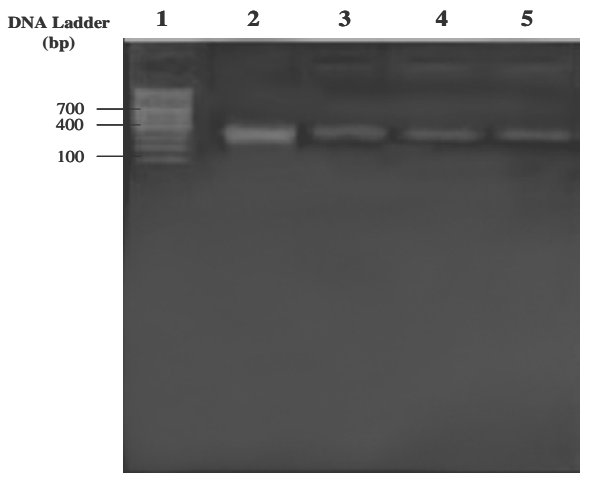

(b)

Figure 1. (a) Agarose gel electrophoresis of PCR products using species-specific primers to amplify B. glabrata ITS2. Lane 1: 100-bp DNA ladder. Lane 2: B. glabrata SBSC strain. Lanes 3-7: Biomphalaria snails from 5 different field localities (2-Giza, 3-Fayoum, 4-Kafr ElSheikh, 5-Damietta, and 6-Ismailia); (b) Agarose gel electrophoresis of PCR products using species-specific primers to amplify $B$. alexandrina ITS1. Lane M: 100-bp DNA ladder. Lane 2: $B$. alexandrina SBSC strain. Lanes 3-5: Biomphalaria snails from 3 different field localities (2-Giza, 3-Fayoum, 4-Kafr El-Sheikh).

(Using laboratory strains of each species) gave the expected results in all assays.

\subsection{DNA Analysis Using RAPD-PCR:-}

All primers examined were successfully amplified on the genomic DNA from pooled samples (3 snails) from each strain (a governorate sample) separately, producing a unique band pattern for each snail strain. Only those bands that showed clear amplification on the pooled samples were scored to ensure the reproducibility of the RAPD marker information.

The amplifications using 4 primers (OPA-1, OPA-9, OPA-18, and LROR) produced RAPD fingerprints (Table 3 and Figures 2(a), (b), (c), (d)) with varying numbers of bands ranging in size from $123.6 \mathrm{bp}$ to $796.6 \mathrm{bp}$ depending on the snail strain and the primer used.

The frequency of each band was considerably different. Three monomorphic bands of (100\%) frequency 


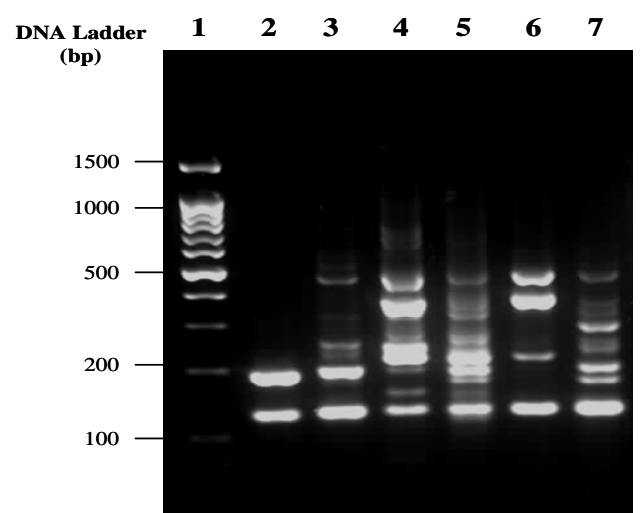

(a)

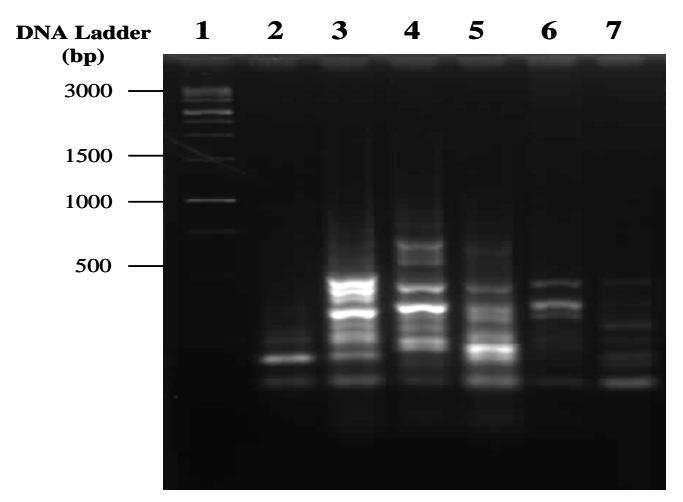

(c)

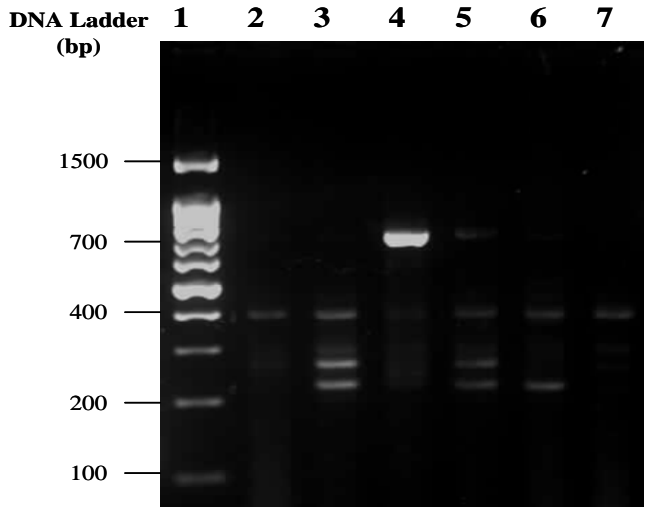

(b)

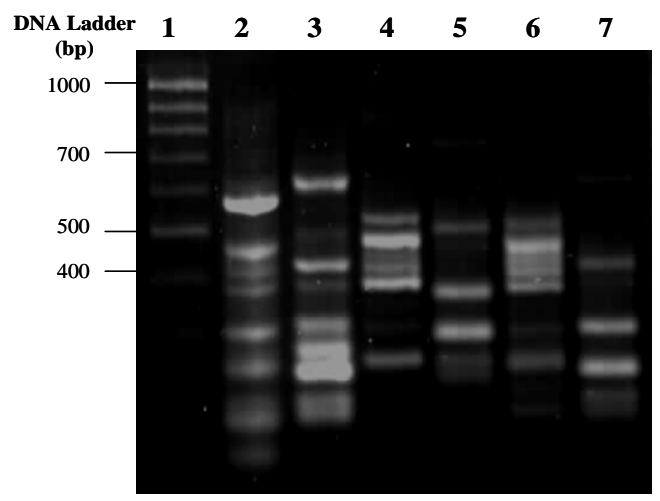

(d)

Figure 2. (a) Agarose-gel electrophoresis of RAPD products generated with OPA-18 arbitrary primer in the six Biomphalaria alexandrina strains; (b) Agarose-gel electrophoresis of RAPD products generated with OPA-9 arbitrary primer in the six Biomphalaria alexandrina strains; (c) Agarose-gel electrophoresis of RAPD products generated with LROR arbitrary primer in the six Biomphalaria alexandrina strains; (d) Agarose-gel electrophoresis of RAPD products generated with OPA-1 arbitrary primer in the six Biomphalaria alexandrina strains.

Table 3. List of primers and number of bands for each B. alexandrina strain investigated with four different random primers.

\begin{tabular}{|c|c|c|c|c|c|c|c|c|c|}
\hline \multirow{2}{*}{ Primer } & \multicolumn{6}{|c|}{ Number of amplified bands } & \multirow{2}{*}{ Total } & \multirow{2}{*}{$\begin{array}{l}\text { Amplified } \\
\text { Bands }\end{array}$} & \multirow{2}{*}{$\begin{array}{l}\text { Polymorphic } \\
\text { Bands }\end{array}$} \\
\hline & SBSC & Giza & Fayoum & Ismailia & $\begin{array}{c}\text { Kafr } \\
\text { EL-Sheikh }\end{array}$ & Damietta & & & \\
\hline 1-OPA-18 & 3 & 6 & 8 & 8 & 5 & 7 & 37 & 24 & 14 \\
\hline 2- OPA-9 & 2 & 4 & 2 & 4 & 2 & 2 & 16 & 8 & 5 \\
\hline 3-LROR & 3 & 6 & 8 & 7 & 4 & 5 & 33 & 18 & 14 \\
\hline 4-OPA-1 & 8 & 7 & 4 & 5 & 5 & 4 & 33 & 29 & 7 \\
\hline Total & 16 & 23 & 22 & 24 & 16 & 18 & 119 & 89 & 40 \\
\hline
\end{tabular}

were recorded among the examined strains which are of size 123.6 bp, 184.2 bp and 406.2 bp. These bands were found in all strains and considered as characteristic bands for B. alexandrina snails. There were 59 bands showed the least frequency (17\%) among the examined strains.

The number of amplified and polymorphic bands generated by each primer is shown in Table 3 . The high- 
est total number of bands (37 bands) was obtained with primer OPA-18 for the 5 governorate strains and SBSC ones, while the lowest number (16 bands) was obtained with OPA-9 primer. Primers LROR and OPA-1 amplified the same total bands number (33 bands). The highest number of polymorphic bands was recorded with primers OPA-18 and LROR being 14. While the lowest number was obtained with primer OPA-1 (5 bands).

Regarding the total bands amplified with all primers in each snail strain, Ismailia snails scored the highest number of bands being 24 bands while the lowest number (16 bands) was recorded for SBSC and Kafr El-Sheikh strains.

The specific markers obtained with the four primers in each strain are shown in Table 4. It is obvious that primer OPA-1 amplified the highest number of specific bands (26 bands). Six bands of molecular weights ranged 132 bp to 538 bp were recorded with SBSC snails. Another six bands with molecular weights 215 bp - 622 bp were scored for Giza, four bands for each of snail strains of Fayoum (230 bp - 506 bp) and Ismailia (265 bp - 779 bp). Three bands of different molecular weights were recorded for Kafr El-Sheikh and Damietta. OPA-9 primer amplified only 5 specific markers, one band of 264 bp for SBSC, two bands for Giza (302 bp and 269 bp), one band of molecular weight 270 bp with Ismailia and another one (308 bp) with Damietta snails. The highest number of specific markers obtained using all primers was recorded in snails of Giza and Damietta being 12 bands, while the lowest (5 bands) was reported for Kafr El-Sheikh snails.

The bands polymorphism obtained with each primer used indicated that the best polymorphism obtained with primer OPA-1 which gave $100 \%$ polymorphism. While the lowest polymorphism (87.5\%) obtained with primer OPA-9 (Table 5). The number of amplified bands per primer varied from 8 (with primer OPA-9) to 29 (with primer OPA-1) with a mean of 22.25 (Table 5).

\subsection{Genetic Relationships among $B$. Alexandrina Strains:}

RAPD markers differences among the pooled DNA samples from each $B$. alexandrina strain were analyzed to assume genetic relationships among populations. The estimated similarity coefficients among B. alexandrina strains ranged from 0.56 to 0.72 . The highest value $(0.72)$ was recorded between the strains of Ismailia and Kafr El-Sheikh, while the lowest (0.56) was scored between the strains of SPSC and Ismailia (Table 6).

The UPGMA dendrogram was performed including

Table 4. DNA specific markers in the six B. alexandrina strains based on the RAPD-PCR analysis.

\begin{tabular}{|c|c|c|c|c|c|}
\hline$\underbrace{\text { primer }}_{\text {Strain }}$ & 1-OPA-18 & 2-ОРА-9 & 3-LROR & 4-OPA-1 & Total \\
\hline SBSC & - & 264 bp & 287 bp & $\begin{array}{l}538 \text { bp } \\
418 \text { bp } \\
376 \text { bp } \\
259 \text { bp } \\
214 \text { bp } \\
132 \text { bp }\end{array}$ & 8 \\
\hline Giza & $\begin{array}{l}533 \text { bp } \\
341 \text { bp } \\
248 \text { bp }\end{array}$ & $\begin{array}{l}269 \text { bp } \\
302 \text { bp }\end{array}$ & 327 bp & $\begin{array}{l}622 \text { bp } \\
391 \text { bp } \\
344 \text { bp } \\
281 \text { bp } \\
240 \text { bp } \\
215 \text { bp }\end{array}$ & 12 \\
\hline Fayoum & $\begin{array}{l}679 \text { bp } \\
197 \text { bp } \\
156 \text { bp }\end{array}$ & - & $\begin{array}{l}796 \text { bp } \\
694 \text { bp } \\
593 \text { bp } \\
322 \text { bp }\end{array}$ & $\begin{array}{l}506 \text { bp } \\
452 \text { bp } \\
348 \text { bp } \\
230 \text { bp }\end{array}$ & 11 \\
\hline Ismailia & $\begin{array}{l}330 \text { bp } \\
189 \text { bp } \\
171 \text { bp }\end{array}$ & 270 bp & $\begin{array}{l}664 \text { bp } \\
339 \text { bp } \\
259 \text { bp }\end{array}$ & $\begin{array}{l}779 \text { bp } \\
486 \text { bp } \\
337 \text { bp } \\
265 \text { bp }\end{array}$ & 11 \\
\hline Kafr EL-Sheikh & $\begin{array}{l}395 \text { bp } \\
257 \text { bp }\end{array}$ & - & - & $\begin{array}{l}500 \text { bp } \\
428 \text { bp } \\
374 \text { bp }\end{array}$ & 5 \\
\hline Damietta & $\begin{array}{l}474 \text { bp } \\
384 \text { bp } \\
293 \text { bp } \\
245 \text { bp } \\
181 \text { bp }\end{array}$ & 308 bp & $\begin{array}{l}402 \text { bp } \\
313 \text { bp } \\
242 \text { bp }\end{array}$ & $\begin{array}{l}642 \text { bp } \\
397 \text { bp } \\
274 \text { bp }\end{array}$ & 12 \\
\hline Total & 16 & 5 & 12 & 26 & 59 \\
\hline
\end{tabular}


Table 5. Comparison of the bands polymorphism with each random primer used in the six B. alexandrina strains based on the RAPD-PCP analysis.

\begin{tabular}{ccccc}
\hline Gel polymorphism & OPA-18 & OPA-9 & LROR & OPA-1 \\
\hline Unique bands & 17 & 5 & 13 & 26 \\
Polymorphic (without Unique) & 6 & 2 & 4 & 3 \\
Polymorphic (with Unique) & 23 & 7 & 17 & 29 \\
Monomorphic bands & 1 & 8 & 18 & 0 \\
Total number of bands & 24 & $\mathbf{8 7 . 5 \%}$ & $\mathbf{9 4 \%}$ & $\mathbf{1 0 0 \%}$ \\
Polymorphism (\%) & $\mathbf{9 5 . 8 \%}$ & 0.334 & 0.306 & 0.190 \\
Mean of band frequency & 0.257 & & & \\
\hline
\end{tabular}

Table 6. Similarity coefficients among six Biomphalaria alexandrina strains from SBSC and five Egyptian governorates based on RAPD PCR profiles.

\begin{tabular}{cccccc}
\hline & SBSC & Giza & Fayoum & Kafr El-Sheikh & Ismailia \\
\hline Giza & 0.66 & & & \\
Fayoum & 0.62 & 0.60 & & \\
Kafr El-Sheikh & 0.69 & 0.68 & 0.67 & 0.72 & 0.59 \\
Ismailia & 0.56 & 0.60 & 0.67 & 0.69 & 0.59 \\
Damietta & 0.64 & 0.58 & & \\
\hline
\end{tabular}

all DNA bands produced by all primers with the six $B$. alexandrina strains (Figure 4).The dendrogram showed three major groups. The first major group contained two strains SPSC and Giza. The second major group split into two subgroups, the first one contained Fayoum strain while the second formed of two strains Ismailia and Kafr El-Sheikh. The third major group contained only Damietta snail strain.

\section{Discussion}

Both B. glabrata and hybrids of B. alexandrina and $B$. glabrata had been previously reported to be occurred in the Nile Delta in Egypt [4,11]. In the present study, species-specific PCR assays were performed to identify Biomphalaria snails collected from the field. According to the results of these assays, all the Biomphalaria snails collected from the field were $B$. alexandrina, and there was no evidence of the presence of $B$. glabrata or of hybrids between them. This agrees with Lotfy et al. [5] who found no evidence for the presence of $B$. glabrata or hybrids of $B$. alexandrina with B. glabrata, in snail samples they collected (including 8 samples from Giza, Qalyoubia, and Kafr El-Sheikh governorates) from the Nile Delta or nearby, Egypt. However, Kristensen et al. [4] utilized RAPD-PCR to differentiate species and populations of Biomphalaria from Egypt and other countries and confirmed that in Nile Delta B. glabrata as well as B. alexandrina is living in the field and it appeared that the hybridization may be occurring between the two.

In the present study, in order to explore the genetic variations and identify specific markers for the differentiation among different $B$. alexandrina strains, a set of 4 random primers with different sequences were used. The primers produced RAPD fingerprints with varying numbers of bands ranging in size from 123.6 bp to 796.6 bp depending on the snail strain and primer used. The RAPD technique constitutes an efficient tool for the study of the DNA polymorphism. It involves the amplification of random segments of genomic DNA by polymerase chain reaction (PCR) using short single primers of arbitrary sequence. RAPD requires very small quantities of DNA while no cloning, sequencing or hybridization is necessary. For these reasons and with the condition that only a little within-group polymorphism exist, it has a marked advantage over other molecular techniques generally used for genomic studies. This technique provides a very efficient and sensitive method for generating genetic markers and constitutes a very attractive tool for studies of genetic variability in populations of different groups of organisms [12-14] including also freshwater snails. Within and between-population genetic diversity of B. glabrata and B. pfeifferi, intermediate hosts of $S$. mansoni, have been analyzed using RAPDs [15-17]. In 


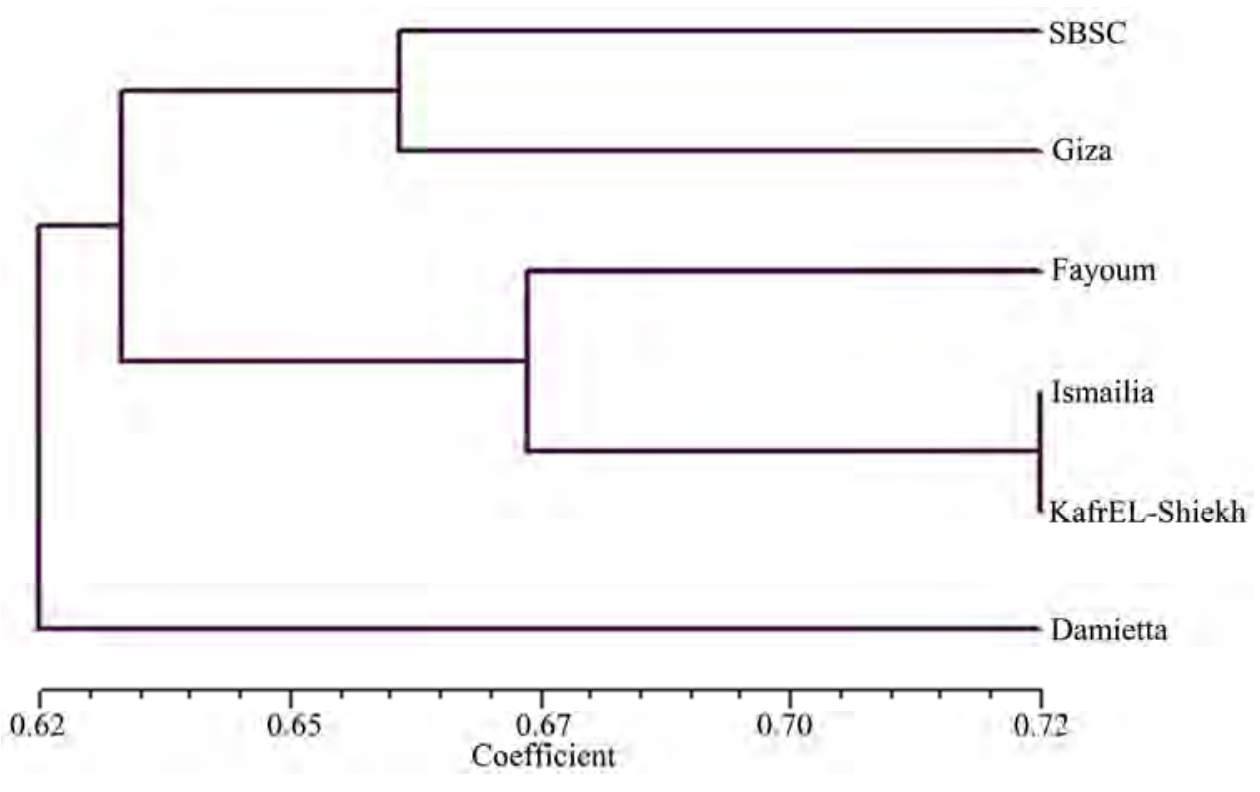

Figure 4. UPGMA cluster analysis showing the diversity and relationship among six Biomphalaria alexandrina strains from SBSC and five Egyptian governorates based on RAPDS profiles.

addition, promising results concerning the use of RAPD-PCR to genetically differentiate resistant and susceptible experimentally selected $B$. glabrata snails to $S$. mansoni miracidia were reported by different authors [18-20]. In Africa, Webster et al. [21] demonstrated how effective RAPD analysis was for investigating intra-specific variation within population of Biomphalaria pfeifferi in Zimbabwe. Also, Abdel-Hamid et al. [7] used RAPD analysis for the study of susceptible and resistant B. tenagophila to S. mansoni. Oliveira et al. [22] used similar technique (RAPD-PCR) to investigate the genetic variability among susceptible and resistant strains within and between B. glabrata and B. tenagophila. They indicated great genetic variations within the two snail species using three different primers, while specimens from the same snail species showed few individual differences between the susceptible and resistant strains.

The present study demonstrates that a short primer of 10 - 20 bp nucleotide sequences could reproducibly amplify segment of DNA from different Biomphalaria strains. The highest total number of bands (37 bands) was obtained with primer OPA-18, while the lowest number was obtained with OPA-9 primer being 16 bands. Ismailia snails scored the highest number of bands being 24 bands while the lowest number (16 bands) was recorded for SBSC and Kafr El-Sheikh strains. The identification of polymorphic bands was based on the comparison of the band patterns on the same gel for the six strains Larson et al. [18]. The polymorphic bands were highest with primers OPA-18 and LROR being 14 bands and lowest with primer OPA-1 (7 bands). Vidigal et al.
[15], employing an equivalent sequence of oligonucleotides, found, in individuals of B. glabrata species, collected from field, polymorphic bands in snails of different places in Brazil. In the present results, obtained using primer OPA-18, which gave numerous polymorphic bands in $B$. alexandrina strains investigated, differ with that obtained by Abu El-Enin [23] who found that this8 primer was the only reproducible marker to identify different strains of Biomphalaria in Egypt. Also, Kristensen et al. [4] used the same primer to differentiate B. alexandrina, B. glabrata and hybrid of both from Egypt and identified B. sudanica from Uganda and B. glabrata from Puerto Rico.

In the present results, the highest number of specific markers obtained using all primers was recorded in snails of Giza and Damietta being 12 bands, while the lowest (5 bands) was reported for Kafr El-Sheikh snails. Regarding the bands polymorphism obtained with each primer used, the best polymorphism was obtained with primer OPA-1 which gave $100 \%$ polymorphism. This primer sound to be useful in differentiating between different $B$. alexandrina strains as it produced the highest number of specific fragments for each snail strain. These specific markers may be associated with resistance or susceptibility of the snail to invading schistosome since, Lewis et al. [20] found that amplification with primer OPA-1 produced a major 180 bp marker in resistant $B$. glabrata snails. Moreover, Spada et al. [24] found a polymorphic marker of 1.100-bp with primer OPA-1, that was repeatedly found only in the susceptible lineages of B. glabrata. Also, Larson et al. [18] obtained, with 
primer OPA-1 a band of 400 bp, characteristic of susceptible lineage ( $\mathrm{M}$ line) of the same snail species. The number of amplified bands per primer varied from 8 (with primer OPA-9) to 29 (with primer OPA-1) with a mean of 22.25. The lowest polymorphism (87.5\%) was obtained with primer OPA-9.

In the present study, the estimated similarity coefficients among $B$. alexandrina strains based on RAPDs profiles ranged from 0.57 to 0.72 . The dendrogram performed including all DNA fragments produced by the four primers with the six B. alexandrina strains showed three major groups. The first contained two strains SPSC and Giza. The second split into two subgroups; one contained Fayoum strain and the other formed of Ismailia and Kafr El-Sheikh strains. The third major group contained only Damietta strain. Nevertheless, such data are not sufficient to indicate that the close populations in the dendrogram may have a common origin, whereas the most distant populations might be introduced from other locations.

In conclusion, this work has revealed that All Biomphalaria snails collected from some water courses in the 5 Egyptian governorates (Giza, Fayoum, Kafr El-Sheikh, Ismailia and Damietta) were Biomphalaria alexandrina snails and no B. glabrata snails were collected. The present study demonstrates that short primers of 10 - $20 \mathrm{bp}$ nucleotide sequences could reproducibly amplify segment of DNA from different Biomphalaria strains. The best polymorphism was obtained with primer OPA-1 which gave $100 \%$ polymorphism. This primer sound to be useful in differentiating between different $B$. alexandrina strains as it produced the highest number of specific fragments for each snail strain.

\section{REFERENCES}

[1] Malek, E.T. (1985) Snail hosts of schistosomiasis and other snail transmitted diseases in Tropical America. A Manual Scientific Publication, PAHO, Washington.

[2] Caldeira, R.L., Jannotti-Passos, L.K. and Carvalho, O.S. (2009) Molecular epidemiology of Brazilian Biomphalaria: A review of the identification of species and the detection of infected snails. Acta Tropica, 111, 1-6. doi:10.1016/j.actatropica.2009.02.004

[3] Ogunkanmi, L.A., Oboh, B., Williams, O., Monu, G. and Ogundipe, O.T. (2009) Phylogenetic and genomic elationships in the genus Malus based on RAPDs. African Journal of Biotechnology, 8, 3387-3391.

[4] Kristensen, T.K., Yousif, F. and Raahauge, P. (1999) Molecular characterization of Biomphalaria species in Egypt. Journal of Molluscan Studies, 65, 133-136. doi:10.1093/mollus/65.1.133

[5] Lotfy, W.M., DeJong, R.J., Kader, A.A. and Loker, E.S. (2005) A molecular survey of Biomphalaria in Egypt: Is B. glabrata present? The American Journal of Tropical
Medicine and Hygiene, 73, 131-139.

[6] Winnepenninckx, B., Backeljau, T. and Wacbier, R. (1993) Extraction of high molecular weight DNA from mollusca, Trends Genetics, 9, 407. doi:10.1016/0168-9525(93)90102-N

[7] Abdel-Hamid, A.H., de Molfetta, J.B., Fernandez, V. and Rodrigues, V. (1999) Genetic variation between susceptible and non-susceptible snails to Schistosoma mansoni infection using random amplified polymorphic DNA analysis (RAPDs). Revista do Instituto de Medicina Tropical de Sao Paulo, 41, 291-295. doi:10.1590/S0036-46651999000500005

[8] Sambrook, J., Fritsch, E.F. and Maniatis, T. (1989) Molecular cloning: A laboratory manual. 2nd Edition, Cold Spring Harbor Laboratory Press, New York.

[9] Nei, M. (1972) Genetic distance between populations. The American Naturalist, 106, 283-292. doi:10.1086/282771

[10] Rohlf, F.J. (2000) NYSYS-pc: Numerical taxonomy and multivariate analysis system. Version 2.10L, Schanket, New York.

[11] Yousif, F., Haroun, N., Ibrahim, A. and El-Bardicy, S. (1996) Biomphalaria glabrata: A new threat for schistosomiasis transmission. Journal of the Egyptian Society of Parasitology, 26, 191-205.

[12] Hadrys, H., Balick, M. and Schierwater, B. (1992) Applications of random amplified polymorphic DNA (RAPD). Molecular Ecology, 1, 55-63. doi:10.1111/j.1365-294X.1992.tb00155.x

[13] Hedrick, P. (1992) Schooting the RAPDs. Nature, 355, 679-680. doi:10.1038/355679a0

[14] Carvalho, S., Caldeira, R.L., Simpson, A.J. and Vidigal, T.H. (2001) Genetic variability and molecular identification of Brazilian Biomphalaria species (Mollusca: Planorbidae). Parasitology, 123, 197-209.

[15] Vidigal, T.H.D.A., Dias Neto, E., Carvalho, O.S., Simpson, A.J.G. (1994). Biomphalaria glabrata: Extensive genetic variation in Brazilian isolates by random amplified polymorphic DNA analysis. Experimental Parasitology, 79, 187-194. doi:10.1006/expr.1994.1078

[16] Hoffman, J.I., Webster, J.P., Ndamba, J. and Woolhouse, M.E. (1998) Extensive genetic variation revealed in adjacent populations of the schistosome intermediate host Biomphalaria pfeifferi from a single river system. Annals of Tropical Medicine and Parasitology, 92, 693-698. doi:10.1080/00034989859159

[17] Langand, J., Théron, A., Pointier, J.P., Delay, B. and Jourdane, J. (1999) Population structure of Biomphalaria glabrata, intermediate snail host of Schistosoma mansoni in Guadeloupe Island, using RAPD markers. Journal of Molluscan Studies, 65, 425-433. doi:10.1093/mollus/65.4.425

[18] Larson, S.E., Anderson, P.L., Miller, N.A., Cousin, C.E., Richrads, C.S., Lewis, F.A. and Knight, M. (1996) Use of RAPD PCR to differentiate genetically defined lines of intermediate host Schistosoma mansoni, Biomphalaria glabrata. The Journal of Parasitology, 82, 237-244. doi:10.2307/3284154

[19] Knight, M., Miller, N.A., Patterson, C.N., Rowe, C.G., Michaels, G., Carr, D., Richards, C.S. and Lewis, F.A. (1999) The identification of markers segregating with resistance to Schistosoma mansoni infection in the snail 
Biomphalaria glabrata. Proceedings of the National Academy of Sciences of USA, 96, 1510-1515. doi:10.1073/pnas.96.4.1510

[20] Lewis, F.A., Patterson, C.N. and Grzywacz, C. (2003) Parasite susceptibility phenotypes of $\mathrm{F}(1)$ Biomphalaria glabrata progeny derived from interbreeding Schistosoma mansoni resistant and susceptible snails. Parasitology Research, 89, 98-101. doi:10.1007/s00436-002-0730-4

[21] Webster, J.P., Davies, C.M., Hoffman, J.I., Ndamba, J., Noble, L.R. and Woolhouse, M.E. (2001) Population genetics of Biomphalaria pfeifferi in the zimbabwean highveld: Implications for co-evolutionary theory. Annals of Tropical Medicine and Parasitology, 95, 203-214. doi:10.1080/00034980120041062

[22] Oliveira, A.L., Da Silva, D., Zanotti-Magalhaes, E.M.,
Abdel-Hamid, A.Z. and Ribeiro-Paes, J.T. (2008) Schistosome/mollusk: Genetic compatibility. Genetics and Molecular Research, 7, 518-526. doi:10.4238/vol7-2gmr444

[23] Abu El-Einin, H.M. (2004) Biological studies on different forms of Biomphalaria snails (Pulmonata, Planorbidae) in Egypt, with relation to their molecular genetics and compatibility to infection with Schistosoma mansoni. Ph.D. Thesis, Ain Shams University, Egypt.

[24] Spada, R.G., Silva, D., Abdel-Hamid, A.Z., Sobral, S.S., Zuim, N.R., Zanotti, M.E., Magalhaes, L.A. and Ribeiro, I.T. (2002) Genetic markers between Biomphalaria glabrata snails susceptible and resistant to Schistosoma mansoni infection. Memórias do Instituto Oswaldo Cruz, 97, 53-58. doi:10.1590/S0074-02762002000900012 